\title{
ANALYSIS OF TRENDS OF HYPERTENSIONS RELATING TO THE LEAVES AND CALCULATIONS IN BLOOD IN EMPLOYEE AND RECOVERY: CASE STUDY IN PLACE OF FINAL DISPOSAL (FD) MEDAN - MARELAN
}

\author{
MUHARNI SAPUTRI*, URIP HARAHAP, MUCHLISYAM \\ Department of Pharmacology, Faculty of Pharmacy, Universitas Sumatera Utara, Medan, Indonesia. Email: muharnisaputri16@gmail.com \\ Received: 04 September 2017, Revised and Accepted: 10 November 2017
}

ABSTRACT

Objective: The aim of this study was to determine the relationship between lead and calcium to hypertension.

Methods: This study uses causal comparative cross-sectional study, which subjects of study as many as 31 people consisting of 10 people in Group I (employees of final disposal [FD]), 17 people in Group II (scavengers who move in FD), and 4 people in Group III (control). Confounding variables in this study are the working period, age, and body mass index. Determining calcium content performed acetylene flame atomic absorption spectrophotometry-air while the lead is done by atomic absorption spectrophotometry graphite furnace method.

Results: The results of the study showed differences of concentration lead of each group. In Group II on day 30 it contained a lead level of $29.9141 \mu$ g/DL. This level has exceeded the threshold set by the WHO. Statistical test results using Rank Spearman correlation showed no relationship between lead and calcium to hypertension, the p value of each group was $0.187,0.819$, and 1.00 .

Conclusion: The results of this study can be concluded that the lead and calcium does not affect blood pressure on employees and scavengers in the FD Medan-Marelan.

Keywords: Hypertension, Lead, Calcium, Final disposal.

(c) 2018 The Authors. Published by Innovare Academic Sciences Pvt Ltd. This is an open access article under the CC BY license (http://creativecommons. org/licenses/by/4. 0/) DOI: http://dx.doi.org/10.22159/ajpcr.2018.v11i2.22360

\section{INTRODUCTION}

One of the factors causing increased blood pressure is the workplace and the uncovered environment. Workers in different industries are regular exposure to heavy metals. Those metals enter their physical structure through various routes (inhalation, food contamination, etc.) and accumulate in the tissues and induce generation of reactive oxygen species (ROS) leading to oxidative damages. Chronic, regular exposures result in a health risk. Certain physiological, biochemical, and behavioral dysfunctions cumulate to pathological conditions. Many of the symptoms complained by those industry workers are hardly known to be related to occupational exposure to heavy metals, often unidentified as occupational health hazards with a story of metalinduced oxidative stress beneath their etiology [1], it's evidenced by a study that included 105 people with arterial hypertension divided into occupational history groups with lead exposure and the group having no work history with lead exposure. This study concluded that lead concentrations were higher in Group I compared with Group II [2]

The workplace or high environment of lead exposure in addition to refueling is the final disposal (FD). In 2011, Chu conducted a survey on heavy metals found in the FD Vietnam that lead metal is more dominant than chromium and cadmium [3]. The various negative impacts arise from FD, from infrastructure damage to environment pollution. The impact of environmental pollution will be very influential in the communities around the FD such as employees and residents. According to Hygiene officials of Medan City Government, stated that every day, the residents are in the FD location, while employees still have a period of leave each month [4]. Exposure prolonged and continuous exposure will have more severe toxic effects [5].

Based on the experience of an observer of lead poisoning in Indonesia states that many lead sources have not been identified or studied, especially lead in contaminated waste in human blood [6]. The lead content in earthworms taken from FD, it was found that the lead content in earthworms was above the threshold [7]. It's very closely related to the FD that is categorized as a source of lead exposure.

Approximately $90-95 \%$ of lead is stored in the bone, while only a small part is found in the blood. The half-life of lead in the blood is only about 30 days [8], whereas according to the WHO (1995) the half-life of lead in blood is approximately $36^{\text {th }}$ days, in soft tissue $40^{\text {th }}$ days, while in bone over 25 years. A researcher stated that lead levels in the blood of volunteers as many as 1052 people experienced of decreasing $40 \%$ in men over 11 years and 30\% in women after 5 years [9]. However, from the bone, lead is demobilized and put into the bloodstream [10], so with the bad effects of lead, lead is a risk factor for hypertensive disease [11].

\section{MATERIALS AND METHODS}

\section{Materials}

Materials were used are pro-quality analysis of E. Merck if not stated otherwise is demineralized water, concentrated $\mathrm{HCl}$, concentrated $\mathrm{HNO}_{3}$, concentrated $\mathrm{HClO}_{4}$, concentrated $\mathrm{H}_{2} \mathrm{SO}_{4}$, volunteers blood, cotton (Bratachem), standard solution of calcium nitrate, the standard solution of lead nitrate, and $\mathrm{Na}_{2}$ EDTA.

The study was conducted using a comparative causal method. Data were collected by interview using a structured questionnaire, including measurement of blood pressure, weight, height, and fill out a questionnaire regarding working time, age, family history, and physical health as well as laboratory analysis, while the approach in this study is cross-sectional. Each volunteer is measured 3 times at intervals for 1 week at $1-21^{\text {th }}$ days. In the previous month should measure the concentration of lead and calcium to see and confirm whether there is a decrease in the concentration of lead and calcium after 1 month. This study was conducted on FD (Group I) employees; scavengers who 
were active in FD (Group II) and control (Group III) were 10, 17, and 4 persons, respectively. The total sample is 31 people.

The study was conducted on FD Medan city Palu Nibung Street, Paya Pasir sub-district, Medan Marelan sub-district and four villages (Jl Marelan Raya Pasar V, Medan Marelan sub-district, Paloh Manan, Deli Serdang sub district, Hamparan Perak district; Titi Pahlawan Pekan Labuhan Street, Medan-Labuhan and Kampung Lama, Deli Serdang district, Hamparan Perak sub-district).

\section{Sample preparation}

Prepare vial previously been given powdered $\mathrm{Na}_{2}$ EDTA as much as $\pm 500 \mathrm{mg}$, then wipe the arm veins radial of volunteers with cotton previously moistened with alcohol $70 \%(\mathrm{v} / \mathrm{v})$, take a syringe the size of $5 \mathrm{ml}$, then take the blood through the veins radial, then insert it into the vial which already contains $\mathrm{Na}_{2}$ EDTA and transported to the laboratory Pharmacy University of North Sumatra for dry destruction.

\section{Process of sample destruction}

Putting blood in a crucible porcelain, put into $5 \mathrm{ml}$ of concentrated nitric acid, heat with digital hot plate in a fume hood for $30 \mathrm{~min}$ at a temperature of $150^{\circ} \mathrm{C}$, add $0.2 \mathrm{ml}$ of perchloric acid $50 \%(\mathrm{v} / \mathrm{v})$ and $0.4 \mathrm{ml}$ of concentrated sulfuric acid and continue heating with the beginning of the heating temperature $150^{\circ} \mathrm{C}$ followed by increasing temperature to $200^{\circ} \mathrm{C}$ and $250^{\circ} \mathrm{C}$ for $15 \mathrm{~min}$. Then ashing followed using a furnace at a temperature of $400^{\circ} \mathrm{C}$ for $48 \mathrm{~h}$. To obtained a perfect ashing can be followed by dissolving with $6 \mathrm{~N} \mathrm{HNO}_{3}$ as much as $10 \mathrm{ml}$ and heated at a temperature $90^{\circ} \mathrm{C}$ for $30 \mathrm{~min}$. A $20 \mathrm{ml}$ puts into a volumetric flask quantitatively and added with demineralized water to the mark line, and then filtered with Whatman filter paper No. 42. Dilute $1 \mathrm{ml}$ of sample solvent and put into $10 \mathrm{ml}$ volumetric flask and heated on quantitative and complete with demineralized water, to the mark line for lead metal and added $5 \mathrm{ml}$ in a $25 \mathrm{ml}$ tinshaped flask for calcium metal and $2.3 \%$ lanthanum oxide solution added $2.5 \mathrm{ml}[12,13]$

\section{Laboratory analysis}

The solution samples obtained from the destruction process in measuring using an AAS method with graphite furnace atomic at a wavelength of $283.3 \mathrm{~nm}$ for lead and $422.7 \mathrm{~nm}$ for calcium with spectrophotometry flame atomization.

\section{RESULTS AND DISCUSSION}

\section{Lead and calcium calibration curves}

The lead and calcium calibration curves were obtained by measuring the absorbance of lead and calcium standard solution with various concentrations at wavelength $283.3 \mathrm{~nm}$ for lead and $422.7 \mathrm{~nm}$ for calcium. The results of measurements of lead and calcium calibration curves can be seen in Figs. 1 and 2 .

The calibration obtained for both lead and calcium (lead $=0.9990$ and calcium $=0.9986$ ), both of it within acceptable ranges of $r \geq 0.95$. This shows that there is a linear correlation of the relationship between concentration $(\mathrm{X})$ and absorbance $(\mathrm{Y})$ which means, the increasing of concentration comparable increased observance [14].

\section{Recapitulation of lead level in blood}

The results of measurements recapitulation in blood for all volunteers can be seen in Table 1.

The result of lead level in blood in Table 1 showed that Group II on the $30^{\text {th }}$ day contained a lead level of $29.9141 \mu \mathrm{g} / \mathrm{dl}$. This level has exceeded the threshold set by the WHO (1995) that is $25 \mu \mathrm{g} / \mathrm{dl}$. Lead levels in Group II on the $37^{\text {th }}$ day decreased. It's happening because the exposure level metals every day is different. In acute lead poisoning, colic occurs with increased blood pressure. Electrocardiographic changes are present in $70 \%$ of patients with common symptoms of tachycardia, Atrial disaritmia, inverted T-wave with/without an abnormal QRS-T complex [15]. A researcher found in his study that a person with a
Table 1: Recapitulation of measurements of lead levels in the blood of all volunteers

\begin{tabular}{lllll}
\hline Group & \multicolumn{4}{l}{ Lead levels in the blood $\mathbf{( m g / d l )}$} \\
\cline { 2 - 5 } & $\mathbf{0}$ days & $\mathbf{3 0}$ days & $\mathbf{3 7}$ days & $\mathbf{5 1}$ days \\
\hline I & 13.3221 & 22.3606 & 11.4673 & 16.2635 \\
II & 15.2584 & 29.9141 & 12.0791 & 22.0720 \\
III & 1.0072 & 5.4340 & 1.1300 & 4.1318 \\
\hline
\end{tabular}

Description: Group I: FD employee, Group II: Scavengers that are active in FD,

Group III: Controls living in the 4-way region of the wind, FD: Final disposal

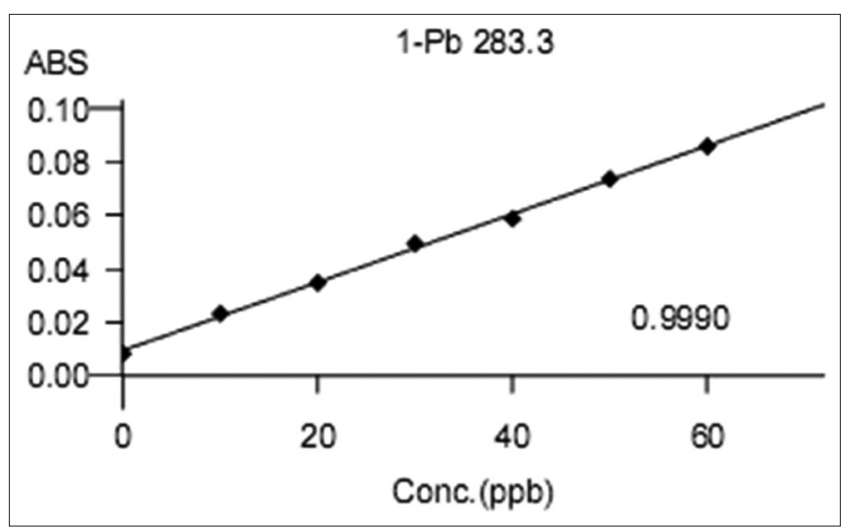

Fig. 1: Calibration curve of lead

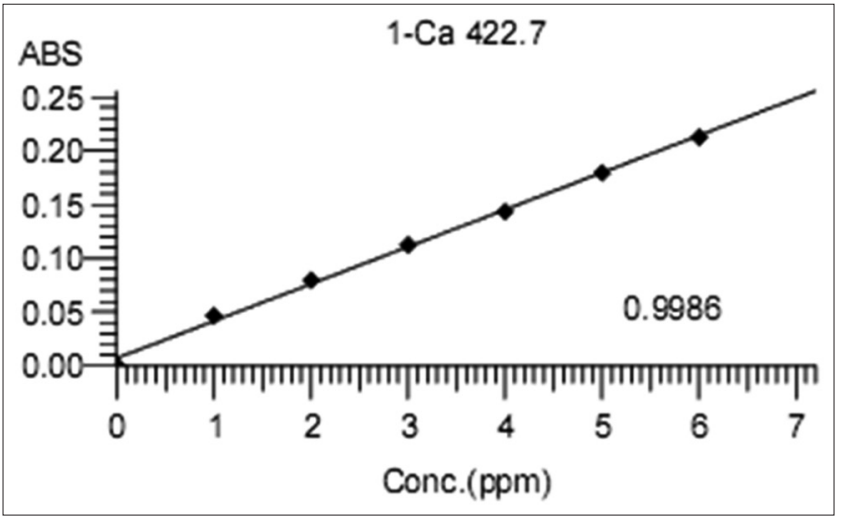

Fig. 2: Calibration curve of calcium

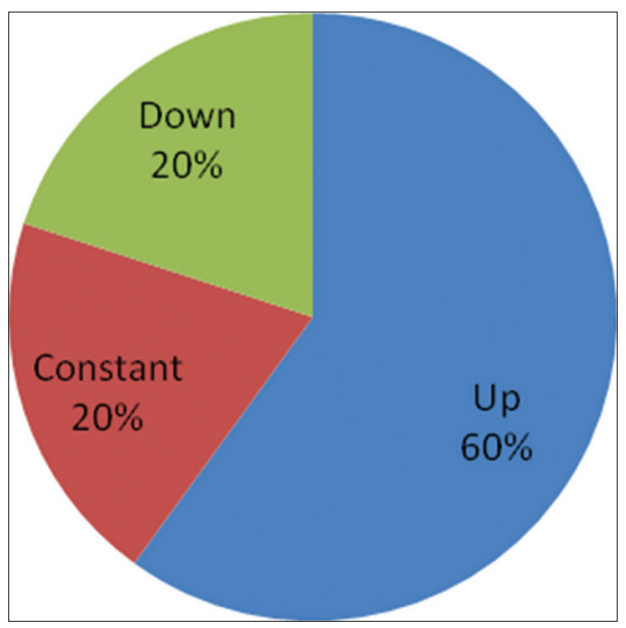

Fig. 3: Percentage diagram of high lead concentration relationship of calcium, blood pressure, and confounding variables 
blood lead level between 20 and $29 \mu \mathrm{g} / \mathrm{dl}$ in $1976 \mathrm{~s} / \mathrm{d} 1980$ showed that increased mortality due to circulatory and cardiac disorder [16].

\section{Levels of calcium in the blood}

The result of measurement recapitulation of blood calcium level in all volunteers can be seen in Table 2 .

The results of recapitulation of blood calcium levels in Table 2 showed that the Groups I and III on the $37^{\text {th }}$ day contained calcium levels of 8.2673 and $7.6586 \mathrm{mg} / \mathrm{dl}$. The level is below the threshold set by Mayus (2013). The amount of normal calcium in the blood is about $9-11 \mathrm{mg} / \mathrm{dl}$ for adults. Based on these criteria, in Group 1, there were $36.36 \%$ of respondents had moderate blood calcium level (9-11 mg/dl) which is still within normal criteria, $18.18 \%$ had low calcium levels $(<9 \mathrm{mg} / \mathrm{dl})$, and $45.45 \%$ or 5 people who have high levels of calcium in the blood.

Increased calcium concentration is not related to lead concentration, but there is a tendency that the higher the concentration of lead, the higher the concentration of calcium. This can be seen in Table 3.

There is a linear relationship between lead and calcium. It's because lead pushes the calcium to the intracellular magnitude and can regulate the inclusion of calcium or calcium release from the sarcoplasmic reticulum. This affects the bond with the sodium-potassium-adenosine triphosphate pump. The excess calcium ion will cause the heart undergoes spastic contraction. This is due to the direct influence of calcium ions in initiating the process of cardiac contraction. This instability of calcium will cause increasing arterioles of smooth muscle contractility thus increasing blood pressure [17]

Table 2: Recapitulation of measurement of blood calcium level in all volunteers

\begin{tabular}{lllll}
\hline Group & \multicolumn{4}{l}{ Calcium levels in the blood $\mathbf{( m g} / \mathbf{d l})$} \\
\cline { 2 - 5 } & $\mathbf{0}$ days & $\mathbf{3 0}$ days & $\mathbf{3 7}$ days & $\mathbf{5 1}$ days \\
\hline I & 11.3715 & 13.5117 & 8.2673 & 8.7255 \\
II & 14.1006 & 14.4211 & 11.8521 & 11.8716 \\
III & 9.3090 & 11.9458 & 7.6585 & 8.5748 \\
\hline
\end{tabular}

Description: Group I: FD employee, Group II: Scavengers that are active in FD, Group III: Controls living in the 4-wind direction, FD: Final disposal

Table 3: Recapitulation of volunteers with high lead and calcium content

\begin{tabular}{llll}
\hline Day & Volunteers & Pb & Ca \\
\hline 0 days & G.1.4 & 27.63 & 24.22 \\
& G.2.5 & 44.85 & 30.79 \\
& G.2.6 & 28.80 & 24.68 \\
30 days & G.2.12 & 53.08 & 35.41 \\
& G.2.13 & 46.03 & 29.96 \\
& G.1.4 & 33.11 & 27.75 \\
& G. 2.5 & 57.98 & 32.36 \\
37 days & G.2.6 & 34.68 & 41.25 \\
& G.2.12 & 56.79 & 41.95 \\
& G.2.13 & 38.91 & 13.47 \\
& G.1.4 & 17.45 & 16.37 \\
51 days & G.2.5 & 5.31 & 24.25 \\
& G.2.6 & 4.92 & 18.02 \\
& G.2.12 & 14.71 & 28.99 \\
& G.2.13 & 11.96 & 18.39 \\
& G.1.4 & 27.13 & 17.68 \\
& G.2.5 & 13.68 & 28.92 \\
& G.2.6 & 14.11 & 29.70 \\
& G.2.12 & 29.42 & 32.44 \\
& G.2.13 & 21.85 & 21.19 \\
\hline
\end{tabular}

Description: G.1: Group I=FD employee, G.2: Group II=scavengers that are active in FD, $\mathrm{Pb}$ : Lead, Ca: Calcium
The relationship between lead, calcium and blood pressure based on time

The test used to determine the relationship between lead to calcium and blood pressure is Rank Spearman. From rank, Spearman Correlation test showed no relation between lead to calcium and blood pressure. The result of the Rank Spearman correlation test in each group can be seen in Table 4

Table 5 summarizes that lead, calcium, and blood pressure show an increase from the $30^{\text {th }}$ day, decreasing on the $37^{\text {th }}$ day, and increasing again on the $51^{\text {st }}$ day.

Recapitulation of volunteers with high lead content related to calcium, blood pressure, age, body mass index (BMI) and years of service

Recapitulation of volunteers with high lead content related to calcium, blood pressure, age, BMI, and years of service can be seen in Table 6 .

Based on data, it can be concluded that, of 5 people who have high lead concentrations, only 3 people have a relationship with calcium, hypertension, and confounding variables, while 2 others have no relationship between lead concentration with calcium, hypertension, and confounding variables, so the percentages can be shown as Fig. 3 .

Based on Table 6 and Fig. 3, the percent increase is greater than the decrease, it suggests that the lead in the blood has put into the bone so that it can induce osteoporosis. The half-life of lead in blood is about 36 days, in soft tissue 40 days, while in the bone is more than 25 years. On the $51^{\text {st }}$ day, there was an increase in the lead concentration of around 40\%; this is due to continuous exposure to lead metal through burning waste, especially plastic which is one of the factors of lead exposure. The basic components in plastic manufacture are lead type support and stearate [18]

Heavy metal enters the cell through various interactions between metal ions and a functional group present at the cell surface and causes toxicity. Heavy metals also cause oxidative stress by generating ROS, including superoxide, hydrogen peroxide, and hydroxyl radical which are highly reactive and toxic and cause damage to a nucleic acid, protein, and lipid [19].

Lead that put into the bloodstream can cause hypertension. Lead can cause increased production of ROS. ROS is a derivative form of oxygen that occurs when reacting with electrons. The main source of ROS is the result of cellular respiration and metabolic processes. In addition, ROS can also occur from radiation. ROS has a crucial part in human physiology and pathophysiological processes. ROS plays a role in the function of immune, thyroid, cognitive, and nutrient sensor modulation and age. In relation to ROS health, it is associated with the implications of several diseases such as cancer, cardiovascular disease (including hypertension), neurological diseases, emotional disorders, and illnesses [20].

\section{CONCLUSION}

Based on the of Rank Spearman's statistical test result, there is no relationship between lead and calcium concentration to increase blood pressure, but visually there is a correlation between lead and calcium to increase individual blood pressure so that the concentration of lead in the blood is one of the factors causing hypertension.

Table 4: The relationship between lead to calcium and blood pressure

\begin{tabular}{llll}
\hline Variable & $\mathbf{P}$ & & \\
\cline { 2 - 4 } & Ex. I & Ex. II & Ex. III \\
\hline Calcium & 0.187 & 0.819 & 1.00 \\
Systole & 0.256 & 0.130 & 0.742 \\
Diastole & 0.053 & 0.157 & 0.684 \\
\hline
\end{tabular}


Table 5: Distribution of lead, calcium and blood pressure

\begin{tabular}{|c|c|c|c|c|c|c|}
\hline \multirow[t]{2}{*}{ Category against lead } & \multirow[t]{2}{*}{ Average group (K) } & \multirow[t]{2}{*}{ Criteria } & \multicolumn{4}{|l|}{ Time } \\
\hline & & & 0 days & 30 days & 37 days & 51 days \\
\hline \multirow[t]{5}{*}{ High } & \multirow[t]{2}{*}{ G.1 (1 Person) } & $\mathrm{Pb}$ & 27.63 & 33.11 & 17.13 & 27.30 \\
\hline & & $\mathrm{BP}$ & $140 / 95$ & $160 / 100$ & $140 / 90$ & $140 / 90$ \\
\hline & \multirow[t]{3}{*}{ G.2 (4 Persons) } & $\mathrm{Pb}$ & 43.19 & 47.09 & 9.23 & 19.77 \\
\hline & & $\mathrm{Ca}$ & 13.53 & 14.47 & 9.98 & 12.90 \\
\hline & & $\mathrm{BP}$ & $143 / 90$ & $140 / 89$ & $138 / 89$ & $145 / 93$ \\
\hline \multirow[t]{6}{*}{ Medium } & \multirow[t]{3}{*}{ G.1 (5 People) } & $\mathrm{Pb}$ & 19.17 & 27.34 & 9.63 & 15.02 \\
\hline & & $\mathrm{Ca}$ & 10.70 & 14.10 & 8.03 & 8.76 \\
\hline & & $\mathrm{BP}$ & $137 / 88$ & $136 / 87$ & $136 / 88$ & $138 / 92$ \\
\hline & \multirow[t]{3}{*}{ G.2 (6 People) } & $\mathrm{Pb}$ & 9.78 & 20.84 & 7.77 & 15.50 \\
\hline & & $\mathrm{Ca}$ & 14.69 & 16.25 & 11.02 & 11.27 \\
\hline & & $\mathrm{BP}$ & $139 / 88$ & $132 / 88$ & $136 / 89$ & $140 / 92$ \\
\hline \multirow{8}{*}{ Low } & \multirow{3}{*}{ G.1 (4 Persons) } & $\mathrm{Pb}$ & 5.41 & 13.44 & 12.26 & 15.09 \\
\hline & & $\mathrm{Ca}$ & 12.06 & 13.04 & 8.81 & 8.90 \\
\hline & & $\mathrm{BP}$ & $143 / 93$ & $148 / 93$ & $145 / 93$ & $145 / 90$ \\
\hline & \multirow{2}{*}{ G.2 (7 People) } & $\mathrm{Ca}$ & 14.06 & 12.75 & 13.83 & 12.18 \\
\hline & & $\mathrm{BP}$ & $133 / 83$ & $134 / 88$ & $135 / 85$ & $130 / 84$ \\
\hline & \multirow[t]{3}{*}{ G.3 (4 Persons) } & $\mathrm{Pb}$ & 1.00 & 5.43 & 1.13 & 4.13 \\
\hline & & $\mathrm{Ca}$ & 9.31 & 11.94 & 7.66 & 8.51 \\
\hline & & $\mathrm{BP}$ & $130 / 83$ & $131 / 81$ & $131 / 84$ & $130 / 83$ \\
\hline
\end{tabular}

Description: G.1: Group I = FD employee, G.2: Group II = scavengers that are active in FD, G.3: Group III = controls living in the 4-way region of the wind, Pb: Lead,

Ca: Calcium, BP: Blood pressure

Table 6: Recapitulation of volunteers with high lead content

\begin{tabular}{|c|c|c|c|c|c|c|c|}
\hline Day & Volunteers & $\mathbf{P b}$ & $\mathrm{Ca}$ & BP & Age & BMI & Years of service \\
\hline \multirow[t]{5}{*}{0 days } & G.1.4 & 27.63 & 24.22 & $140 / 95$ & 44 & Normal & 13 \\
\hline & G.2.5 & 44.85 & 30.79 & $130 / 80$ & 25 & Normal & 6 \\
\hline & G.2.6 & 28.80 & 24.68 & $140 / 90$ & 42 & Normal & 20 \\
\hline & G.2.12 & 53.08 & 35.41 & $140 / 85$ & 48 & $<\mathrm{BW}$ & $>20$ \\
\hline & G.2.13 & 46.03 & 29.96 & $160 / 100$ & 58 & $>\mathrm{BW}$ & $>20$ \\
\hline \multirow{4}{*}{30 days } & G.1.4 & 33.11 & 27.75 & $160 / 100$ & 44 & Normal & 13 \\
\hline & G.2.5 & 57.98 & 32.36 & $130 / 90$ & 25 & Normal & 6 \\
\hline & G.2.12 & 56.79 & 41.95 & $140 / 85$ & 48 & $<\mathrm{BW}$ & $>2$ \\
\hline & G.2.13 & 38.91 & 13.47 & $160 / 100$ & 58 & $>\mathrm{BW}$ & $>20$ \\
\hline \multirow[t]{5}{*}{37 days } & G.1.4 & 17.45 & 16.37 & $140 / 90$ & 44 & Normal & 13 \\
\hline & G.2.5 & 5.31 & 24.25 & $135 / 85$ & 25 & Normal & 6 \\
\hline & G.2.6 & 4.92 & 18.02 & $130 / 80$ & 42 & Normal & 20 \\
\hline & G.2.12 & 14.71 & 28.99 & $130 / 90$ & 48 & $<\mathrm{BW}$ & $>20$ \\
\hline & G.2.13 & 11.96 & 18.39 & $160 / 90$ & 58 & $>$ BW & $>20$ \\
\hline \multirow[t]{4}{*}{51 days } & G.1.4 & 27.13 & 17.68 & $140 / 90$ & 44 & Normal & 13 \\
\hline & G.2.6 & 14.11 & 29.70 & $140 / 90$ & 42 & Normal & 20 \\
\hline & G.2.12 & 29.42 & 32.44 & $140 / 90$ & 48 & $<\mathrm{BW}$ & $>20$ \\
\hline & G.2.13 & 21.85 & 21.19 & $160 / 100$ & 58 & $>\mathrm{BW}$ & $>20$ \\
\hline
\end{tabular}

Description: G.1: Group I=FD employee, G.2: Group II=scavengers that are active in FD, Pb: Lead, Ca: Calcium, BP: Blood pressure, BW: Body weight

\section{CONFLICTS OF INTEREST}

All author have none to declare.

\section{AUTHOR CONTRIBUTION}

Pharmaceutical Technology, Pharmaceutics, Novel Drug Delivery, Biopharmaceutics, Pharmacokinetics.

\section{REFERENCES}

1. Debasish B, Debosree G, Aindrila C, Elina M. Curry leaves as alternative medicine in heavy metal induced occupational health hazards. Int J Pharm Pharm Sci 2016;8:8-20.

2. Poreba P, Antonowicz J, Andrzejak R. The relationship between occupational exposure to lead and local arterial stiffness and left ventricular diastolic function in individuals with arterial hypertension.
J Toxicol Appl Pharm 2011;254:342-8.

3. Ajah KC, Ademiluyi J, Nnaji CC. Spatiality, seasonality and ecological risks of heavy in the vicinity of a degenerate central municipal dump site in Enugu, Nigeria. J Environ Health Sci Eng 2015;13:1-14

4. Muamar A. Every day, Garbage in Marelan Final Disposal to 1500 tons in 2015. Newspaper of Tribun Medan.

5. Palar H. Pollution and Toxicology Heavy Metals. Jakarta: Rineka Copyright; 2008.

6. Suherni. Lead Poisoning in Indonesia. Global lead Advice and Support Service. Thesis, 2010. Sydney, Australia: Graduate School of the Environment, Macquarie University.

7. Ulfa SF. Analysis of Lead $(\mathrm{Pb})$ and Cadmium $(\mathrm{Cd})$ Content in Earthworm Atomic Absorption Spectrophotometry (AAS). Thesis, 2010. Medan: University of North Sumatera.

8. Victery W, Tyroler H, Vospe R, Grant LD. Summary of Discussion Sessions: Symposium on Lead-blood Pressure Relationship. Environ Health Perspect 1988;78:139-55. 
9. Møller L, Kristensen TS. Blood lead as a cardiovascular risk factor. Am J Epidemiol 1992;136:1091-100.

10. Rustanti I, Mahawati E. The factors related to blood lead levels in the driver of public transports of karang ayu-panggaron in semarang. J Visikes 2011;10:59-68.

11. Martin D, Glass TA, Bandeen RK, She W, Schwartz BS. Todd air conditioning. Association of blood lead and tibia lead with blood pressure and hypertension in a community sample of older adults. Am J Epidemiol 2006; 163:467-78.

12. Muchlisyam HU, Silalahi J, Alfian Z. Binding ability of corn cobs hemicellulose toward cadmium. Am J Chem 2013;4:86-93.

13. Haswell SJ. Atomic Absorption Spectrometry. Vol. 202. New York: Elsivier, Amsterdam; 1991. p. 207-8.

14. Sudjana N. Statistical Methods. $6^{\text {th }}$ ed. Bandung: Publisher Tarsito; 2005. p. 371.
15. Adnan S. The influence of lead exposure on the health and quality of male workers cement. Ind Med Mag 2001;51:168-74.

16. Lustberg M, Silbergeld E. Blood lead levels and mortality. Arch Intern Med 2002;162:2443-9.

17. Brozovich FV, Nicholson CJ, Degen CV, Gao YZ, Aggarwal M, Morgan KG. Mechanism of vascular smooth muscle contraction and the basic for pharmacologic treatment of smooth muscle disorder. Pharmacol Rev 2016;68:476-532.

18. Coyle P, Kosnett MJ, Hipkins K. Severe lead poisoning in the plastics industry: A report of three cases. Am J Ind Med 2005;47:172-5.

19. Gupta S, Singh S, Sharma S. Tolerance against heavy metal toxicity in cyanobacteria: Role of antioxidant defense system. Int J Pharm Pharm Sci 2015;7:9-16.

20. Urso G. Oxidative caimi stress and endothelial dysfunction. Minerva Med 2011;102:59-77. 